CONF-8810155--4

DE89 002192

\title{
HSST HIDE-PLATE TEST RESULTS AND ANALYSIS
}

D. J. Naus, B. R. Bass and J. Keeney-Walker Oak Ridge Nacional Laboracory (ORNL)

Oak Ridge, Tennessee 3783 I

and

R. J. Fields, R. deWit and $S$. R. Low III

National Insticute of Standards and Technology (NIST)

Caithersburg, Maryland 20899

\footnotetext{
"The submitted manuscript has been authored by a contractor of the U.S. Government under contract No. DE-AC05-840R21400. Accordingly. the U.S. Government retains a nonexclusive, royalty-free license to publish or reproduce the published form of this contribution, or allow others to do so. for U.S. Government purposes.-
}

\section{DISCLAIMER}

This report was prepared as an account of work sponsored by an agency of the United States Government. Neither the United States Government nor any agency thereof, nor any of their employees, makes any warranty, express or implied, or assumes any legal liability or responsibility for the accuracy, completeness, or usefulness of any information, apparatus, product, or process disciosed, or represents that its use would nut infringe privately owned rights. Reference herein to any specific commercial product, process, or service by trade name, trademark, manufacturer, or otherwise does not necessarily constitute or imply its endorsement, recommendation, or favoring by the United States Government or any agency thereof. The views and opinions of authors expressed herein do not necessarily state or reflect those of the United States Government or any agency therenf. 
1). J. Naus, B. R. Bass and J. Keeney-Walker

Oak RIdge National Laboratory (ORNL)

Oak Ridge, Tennessee 37831

and

R. J. Fields, R. dewit and S. R. Low III

National Institute of Standards and Technology (NIST)

Gaithersburg, Maryland 20899

\section{ABSTRACT}

Fifteen wide-plate crack-arrest tests have been completed to date, ten utilizing specimens fabricated from A533B class 1 material (WP- 1 and WP-CE serles), and five fabricated from a low upper-shelf base material (WP-2 series). Each test utilized a single-edge notched specimen that was subjected to a linear thermal gradient along the plane of crack propagation. Test results exhibit an increase in crack-arrest toughness with temperature, with the rate of increase becoming greater as the cemperature increases. When the wide-plate test results are combined with other large-specimen results the data show a consistent trend in which the $K_{L a}$ data extends above the limic provided in ASME Section XI.

\section{l. INTRODUCTION}

Current light-water reactor (LWR) pressure-vessel safety assessment methods are based in large measure on Sects. III and XI of the American Society of Mechanical Engineers (ASME) Boiler and Pressure Vessel Code (B\&PVC). In pressurized-thermal-shock (PTS) scenarlos, flaws on the inner surface of a reactor pressure vessel (RPV) have the greatest propensity to propagate because they are in the region of highest thermal stress, lowest temperature, and greatest irradiation damage. If such a flaw begins to propagate radially through the vessel wall, it will extend into a region of higher fracture toughness due to the higher temperatures and less irradiation damage. Although the thermal stresses may decrease with propagation depth, the stressintensity factor caused by the elevated-pressure loading will be Increasing.

The fracture toughness correlations contained in the ASME B\&PVC embody the position that one cannot assume a crack-arrest toughness value ( $\mathrm{K}_{\mathrm{Ia}}$ ) above $220 \mathrm{MPa} \cdot \sqrt{\mathrm{m}}$ for LWK pressure-vessel steels. The imposition of this limit is

* Kesearch sponsored by the Office of Nuclear Regulatory Research, U.S. Nuclear Regulatory Commission under Interagency Agreement 1886-8011-9B with the U.S. Department of Energy under Contract DE-ACOS-840R21400 with Martin Marietta Energy Systems, inc. 
based la pare on the $l a c l$ that no $k_{\text {la }}$ data exisled at or above this level and because Charpy tests ihuwed that impact energy levels exhibit all upper shelf behavior. Therefore, the nacure of crack-artest behiviur and $k_{\text {la }}$ excrapolations to temperatures higher than that at which this limit occurred could not be presumed.

The ASME limit does not impose difficulties in making assessments for LWR pressure vessels undergoing thermal shock transients with low accompanying pressure levels. However, PTS scenarlos could lead to conditions where the driving force on a propagating crack increases to levels well in excess of the current ASME limit. Thus, safety assessment methods for this type of condition would require an understanding of the following points.

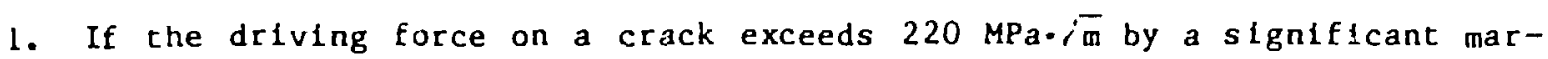
gin, can the material exhibit crack-arrest behavior?

2. If the materials do exhibit high $K_{\mathrm{J}}$ values with increasing temperature, what is the relationship between $k_{I a}^{a}$ and remperature? That is, does a temperature limit exist above which cleavage crack propagation cannot continue regardless of how high the driving force?

3. If crack arrest does occur at high temperatures where the material behavior is typically dominated by ductile behavior, then what interactions exist between the various fracture modes, including arrest, stable crack growth, unstable crack growth, and tensile instability?

\section{PROGRAM OBJECTIVE AND GOALS}

The primary objective of the wide-plate crack-arrest studies is to generate data and associated analysis methods for understanding the crack-arrest behavior of prototypical RPV steels at temperatures neat and above the onset of the Charpy upper-shelf region. Program goals include (1) extending the existing $\mathrm{K}_{\mathrm{Ia}}$ data bases to values above those associated with the upper limit in the $A S M E B \& P V C$; (2) clearly establishing that crack arrest occurs prior to fracture-mode conversion; and (3) validating the predictability of crack arrest, stable tearing, and/or unstable tearing sequences for ductile materials. The wide-plate tests and analyses provide bases for obtaining and interpreting dynamic-fracture data (with relatively loig crack runs) and bases for validation of viscoplastic fracture models and analysis methods.

\section{MATERIAL PROPERTIES}

\subsection{WP-1 Test Series (A533B Material)}

The initial series of wide-plate crack-arrest specimens is caken from the central portion of a 18.73 - cm-thick plate of A533 grade B class 1 steel that is in a quenched and tempered condition. Properties of the plate include Young's modulus $(E)=206.9 \mathrm{GPa}$, Poisson's ratio $(v)=0.3$, coefficient of thermal expansion $(\alpha)=11 \times 10^{-6} /{ }^{\circ} \mathrm{C}$, and density $(p)=7850 \mathrm{~kg} / \mathrm{m}^{3}$. The 
temperature-dependent yleld stress for the material is given by

$$
a_{y}=374.87+59.89 e^{-0.00793 T}
$$

where $o_{y}$ and $T$ have units in megapascals and degrees Celclus, respectively. The ultimate strength of the material, for use in tensile instability calculations, is based on the average stress in the remalning ligament ( $\sigma_{u}$ ) equal to $550 \mathrm{MPa}$, which represents the lowest value determined for the temperature range of interest. For tearing instabllity calculations, the materlal tearing resistance is assumed to be given in the form of a power-law J-resistance curve

$$
\mathrm{J}_{\mathrm{K}}=\mathrm{c}(\Delta \mathrm{a})^{\mathrm{m}}
$$

where $c=0.3539, m=0.4708$, and the units of $J_{R}$ and $\Delta a$ are $\mathrm{MJ} / \mathrm{m}^{2}$ and mm, respectively. Temperature-dependent fracture-toughness relations for initiaclon and arrest, based on small-specimen data, are given by

$$
\begin{aligned}
& K_{I c}=51.28+51.90 e^{0.036\left(T-R T_{N D T}\right)} \\
& K_{I a}=49.96+16.88 e^{0.029\left(T-R T_{N D T}\right)}
\end{aligned}
$$

with units for $K$ and $T$ belng $M P a \cdot \sqrt{m}$ and ${ }^{\circ} \mathrm{C}$, respectively. Drop-welght and Charpy $V$-notch test data indicate that $R T_{N D T}=-23^{\circ} \mathrm{C}$, and Charpy upper-shelf energy is $160 \mathrm{~J}$ with its onset occurring at $55^{\circ} \mathrm{C}$.

Analytical studies have used a dynamic fracture toughness relation in the following form:

$$
K_{I D}=K_{I a}+A(T) \dot{a}^{2}
$$

where $\mathrm{K}_{\mathrm{Ia}}$ is given by Eq. (4) and

$$
A(T)=\left[329.7+16.25\left(T-R_{N D T}\right)\right] \times 10^{-6},
$$

or

$$
A(T)=\left[121.71+1.296\left(T-\mathrm{RT}_{\mathrm{NDT}}\right)\right] \times 10^{-6},
$$

if $\left(\mathrm{T}-\mathrm{RT}_{\mathrm{NDT}}\right)$ is greater or less than $-13.9^{\circ} \mathrm{C}$, respectively. Units for $\mathrm{K}_{\mathrm{ID}}$, $A, \dot{a}$, and $T$ are megapascals times root meters, megapascals times square seconds times meters to the $-3 / 2$, meters per second, and degrees Celclus, respectively. The form of the $K_{I D}$ expiession $\mathrm{In} \mathrm{Eq}$. (5) and relations for 
A(T) |Eqs. (6) and (7) | are derlved from kef. |l| by est Imat Ing that $K T_{\text {NUT }}=-6.1^{\circ} \mathrm{C}$ for the materlal used In that study.

3.2 WH-CE Test Serles (A533B Materlal)

The WP-CE specimens were made fron a second heat of $A 533$ grade B class 1 material that was provided to ORNL by Combustion Englneering (CE), Inc. The material was characterized by $C E$, and the detalled resuits are presented in Ref. [2]. Pertinent macerlal propertles lnclude:

1. an ultimate tensile strength ranging from $-580 \mathrm{MPa}$ at room temperature to $=560 \mathrm{MPa}$ at $66^{\circ} \mathrm{C}$ to $-520 \mathrm{MPa}$ at $120^{\circ} \mathrm{C}$,

2. a nil-ductility transition temperature from $*-34$ to $-23^{\circ} \mathrm{C}$,

3. a Charpy upper-shelf energy of -180 to $-203 \mathrm{~J}$, and

4. the minimum temperature for fully ductile behavior occurring at $=43$ to $\sim 49^{\circ} \mathrm{C}$.

Temperature-dependent fracture-toughness relations for the WP-CE material used Eor pretest planning were the same as Eqs. (3) and (4) with the RT NDT changed to the appropriate value for the WP-CE material.

\subsection{WP-2 Test Series (Low Upper-Shelf Material)}

The WP-2 series of wide-plate crack-arrest specimens is taken from a 15.88-cm thick plate of $21 / 4 \mathrm{Cr}-1$ Mo steel. The material was supplied by Babcock and Wilcox after being heat treated in an effort to obtain a Charpy upper shelf energy of 68 joules $(50 \mathrm{ft}-1 \mathrm{~b})$, or less.

Based on a limited number of tests, the centative drop-weight nil-ductility temperature for the material is $\sim 60^{\circ} \mathrm{C}$, and the Charpy upper-shelf energy $1 \mathrm{~s}$ about $60 \mathrm{~J}$ with its onset occurring at about $150^{\circ} \mathrm{C}$. The ultimate strength of the material, for use in tensile instability calculations, is based on the average stress in the remaining ligament $\left(\sigma_{u}\right)$ equal to $500 \mathrm{MPa}$. For tearing instability conditions, the values of $c$ and $m$ in $\mathrm{Eq}$. (2) are 0.1114 and 0.3832 , respectively. Tentative temperature-dependent fracture-toughness relations for initiation and arrest, which have been used for planning the WP2 series tests are given by:

$$
\begin{aligned}
& K_{I_{c}}=39.53+93.47 \mathrm{e}^{0.036\left(T-D W_{N D T}\right)} \\
& K_{I_{a}}=22.31+62.69 \mathrm{e}^{0.0177\left(T-D W_{N D T}\right)}
\end{aligned}
$$

with units of $\mathrm{K}$ and $\mathrm{T}$ belng $\mathrm{MPa} \cdot \sqrt{\mathrm{m}}$ and ${ }^{\circ} \mathrm{C}$, respectively, and the material $\mathrm{DW}_{\text {NDT }}=60^{\circ} \mathrm{C}$. The dynamic fracture toughness relation is presented in Eq. (5) with $60^{\circ} \mathrm{C}$ used as the material $\mathrm{RT}_{\mathrm{NDT}}$. 
The $1 \times 1 \times 0.1 \mathrm{~m}$, or $1 \times 1 \times 0.15 \mathrm{~m}$, speclmens such as shown $1 \mathrm{n} F \mathrm{fg}$. 1 , were machined and precracked by ORNL. The precracking was done by hydrogen charging an electron-beam (EB) weld located at the base of a premachined notch in the plate. The total crack length, notch depth plus EB weld, for each specimen was nominally 0.2 an $(a / W \sim 0.2)$ and the $f$ law was orlented perpendicular to the rolling direction. Each side of a specimen was side grooved to a depth equal to 12.57 of the plate thickness. Starting with the third specimen in test series WP-l (WP-1.3), the crack front of each specimen, with the exception of specimen WP-2.3, was machined into a truncated chevron configuration to reduce the tensile load required to achieve crack initiation. Upon completion of the machining operations each specimen was shipped to NIST where ic was welded to pull plates nominally having the same cross-section geometry as the specimen. A specimen pinto-pin length of approximately 9.6 m was selected tu minimize stress wave effects. Tables 1,2 and 3 present dimensions for each of the specimens in the WP-l, WP-CE and WP-2 test series, respectively, which have been tested to date.

CRACK PLANE (SIDE GROOVED),
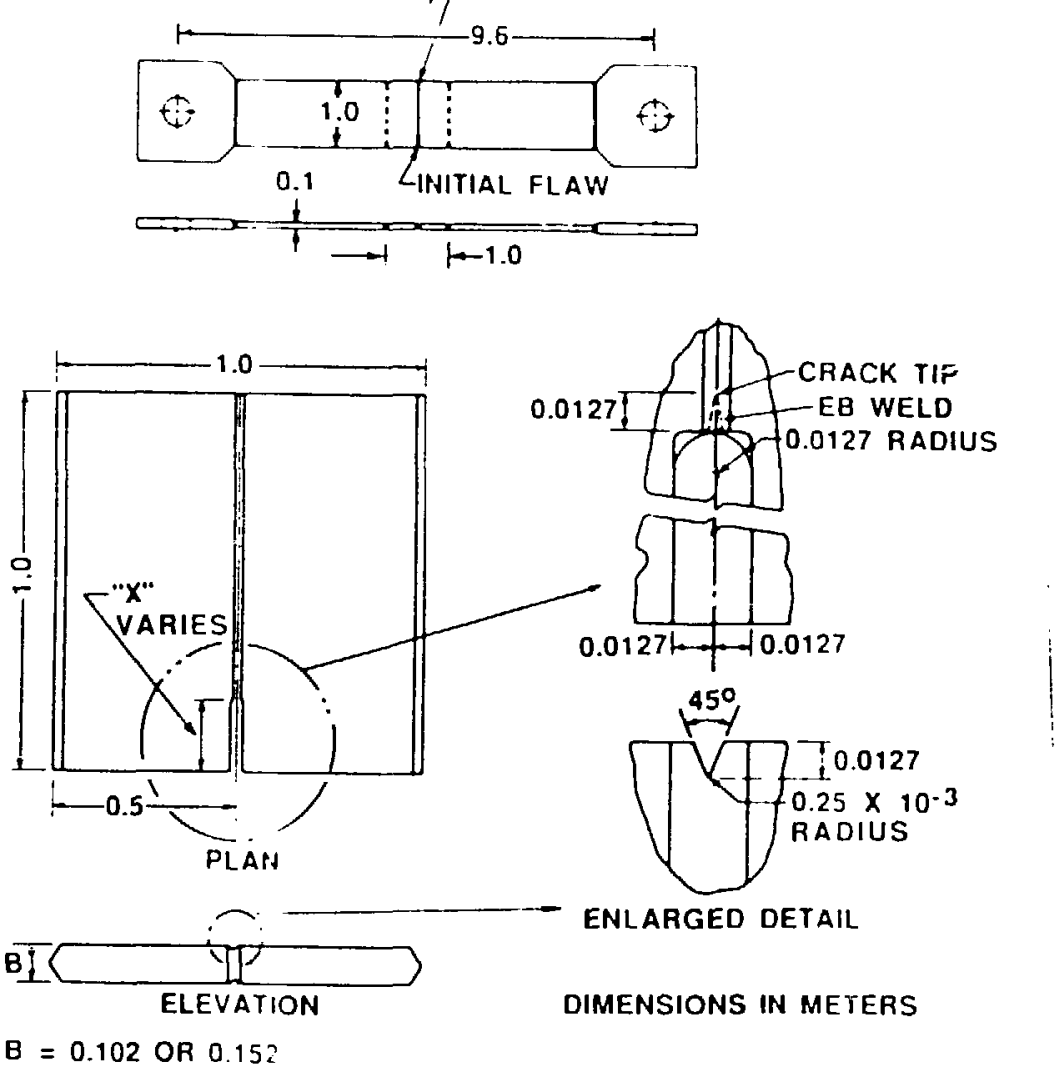

Fig. L. Schematic of HSST wide-plate crack-arrest specimen. 
TABLE 1

WP-1 SERIES TEST SPECIMEN DIMENSIONS

\begin{tabular}{|c|c|c|c|c|c|c|c|c|c|}
\hline \multirow{3}{*}{ Dimenston } & \multirow{3}{*}{ Symbol } & \multicolumn{8}{|c|}{ Dimension $(\mathrm{mm})$} \\
\hline & & \multicolumn{8}{|c|}{ Specimen designation } \\
\hline & & WP-1.1 & WP- 1.2 & $W P-1.3$ & $W P-1.4$ & $W P-1.5$ & $W P-1.6$ & $W P-1.7$ & $W P-1.8$ \\
\hline Initlal crack length & $a_{0}$ & 196.9 & 199 & 197 & 207.5 & 200 & 200 & 202 & 198 \\
\hline Thickness & B & 101 & 101.8 & 99.5 & 99.6 & 101.7 & 101.8 & 152.4 & 152.4 \\
\hline Notched thickness & ${ }^{B} \mathbf{N}$ & 76.3 & 77.5 & 75.4 & 76.9 & 76.4 & 75.5 & 114.3 & 115.1 \\
\hline $\begin{array}{l}\text { Chevron thlckness } \\
\left(\text { thlckness at } a_{0}\right)\end{array}$ & ${ }^{\mathrm{B}} \mathrm{C}$ & $\mathrm{NA}^{a}$ & $\mathrm{NA}^{a}$ & 47.5 & 33.8 & 41.2 & 40.0 & 61.0 & 56.2 \\
\hline Width & 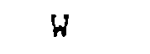 & 997 & 998 & 1000 & 1000 & 1000 & 1000 & 1000 & 1000 \\
\hline
\end{tabular}

$a_{\text {Not applicable. }}$ 
TABLE: 2

WP-CE SERIES TEST SPECIMEN DIMENSIONS

\begin{tabular}{|c|c|c|c|}
\hline & \multirow{3}{*}{ Symbol } & \multicolumn{2}{|c|}{ Dimenston (mm) } \\
\hline & & \multicolumn{2}{|c|}{ Specimen designation } \\
\hline & & $W P-C E-1$ & WP-CE-2 \\
\hline Inicial crack lengch & $a_{0}$ & 200 & 201 \\
\hline Thickness & B & 101.7 & 101.8 \\
\hline Notch thlckness & $B_{N}$ & 76.3 & 76.2 \\
\hline $\begin{array}{l}\text { Chevron thickness } \\
\left(\text { chickness at } a_{0}\right)\end{array}$ & ${ }^{B} \mathrm{C}$ & 40.0 & 40.4 \\
\hline Width & $W$ & 1000 & 999.5 \\
\hline
\end{tabular}

TABLE 3

WP-2 SERIES TEST SPECIMEN DIMENSIONS

\begin{tabular}{|c|c|c|c|c|c|c|}
\hline \multirow{3}{*}{ Dimension } & \multirow{3}{*}{ Symbol } & \multicolumn{5}{|c|}{ Dimension (mm) } \\
\hline & & \multicolumn{5}{|c|}{ Specimen designation } \\
\hline & & $W P-2.4$ & WP-2.1 & WP-2.5 & $W P-2.3$ & WP-- 2.2 \\
\hline Initial crack length & $a_{0}$ & 203 & 202.6 & 199 & 200 & 213 \\
\hline Thickness & B & 101.7 & 152.3 & 101.6 & 152.4 & 152.4 \\
\hline Notch thickness & $\mathbf{B}_{\mathbf{N}}$ & 76.3 & 113.9 & 76.2 & 113.8 & 113,8 \\
\hline $\begin{array}{l}\text { Chevron thickness } \\
\text { (thickness at } a_{0} \text { ) }\end{array}$ & ${ }^{\mathrm{B}} \mathrm{C}$ & 40.5 & 61.5 & 40.7 & $b$ & 71.9 \\
\hline Width & $\mathrm{H}$ & 1000 & 1000 & 999 & 1000 & 1000 \\
\hline Pop-in crack length & $a_{a}^{\infty}$ & 251 & $\mathrm{NA}^{a}$ & 264 & $N A^{a}$ & $\mathrm{NA}^{a}$ \\
\hline $\begin{array}{l}\text { Chevron thickness } \\
\left.\text { (thickness at a } a_{0}^{\prime}\right)\end{array}$ & ${ }^{B}{ }_{C}^{c}$ & 75.5 & ${ }_{10} \mathrm{~A}^{a}$ & $\mathrm{NA}^{a}$ & $b$ & $b$ \\
\hline $\begin{array}{l}a_{\text {Not applicable }} \\
\text { and wP-2.3) or the } c \\
\text { of the plate where th } \\
b_{\text {Specimen ron-ch }}\end{array}$ & $\begin{array}{l}\text { cause } \\
k \text { leng } \\
\text { crack } \\
\text { roned. }\end{array}$ & her a & $\begin{array}{l}-i n d i \\
-i n(a\end{array}$ & $\begin{array}{l}\text { not occ } \\
\text { was } p a \\
\text { oned ( }\end{array}$ & $\begin{array}{l}(W P-2 . \\
\text { the re } \\
2.5)\end{array}$ & $\begin{array}{l}\text { WP-2.2 } \\
\text { on }\end{array}$ \\
\hline
\end{tabular}




\subsection{Instrumencalion}

Up to 40 thermocouples were positioned on each specimen as shown in fig. 2. buring the heating cooling processes, the 20 thermocouples adjacent to the crack plane were displayed graphically in real time to indicate the relationship between the actual and desired thermal gradlent across the specimen width. The 20 additional thermocouples indicated the temperature distribution at other positions on the specimen and pull plates and were used prirarily for post-test analyses.

Although the number of strain gages has varied from test to test, up to a total of 25 gages have been utilized to provide dynamic straln-field measurements for determination of crack velocity and assessing boundary conditions. Strain gage locations utilized for tests WP-1.7 and WP-CE-1 are shown in Fig. 3. The crack-line gages (numbers 1 through 20 in Fig. 3) were twoelement, $90^{\circ}$ stacked, 350-ohm Karma alloy (nickel-chromium alloy) gages on a polyimide backing. Near and $f a r$ field gages were either uniaxial or threeelement 350-ohm constantan alloy gages. The strain gage signals were recorded either by a trarisient digital oscilloscope or a combination of oscilloscopes and a multichannel, wide band, frequency modulated, magnetic tape recorder. Operations of the oscilloscopes and recorder during a test were controlled by the microcomputer-based system shown schematically in Fig. 4.

Addicional instrumentation that have been used in selected tests include: (1) capacitance-based crack-opening-displacement gages mounted on the front and back plate faces at an a/W that varled from 0.120 to 0.175 , (2) an acoustic emission transducer located on the specimen lower pull tab, (3) a displacement gage mounted on the specimen centerline approximately 3.5 m below the crack plane, and (4) accelerometers mounted on the specimen centerline approximately $3.5 \mathrm{~m}$ below and $3.5 \mathrm{~m}$ above the crack plane. More detailed information on the instrumentation systems can be obtained from Ref. [3].

\subsection{Heating-Cooling-Insulation Systems}

After being instrumented, the specimen was placed into the NIST testing machine and individual electric-resistance strip heaters attached to the back edge of the plate. The primary heating zone was formed by two pairs of heaters attached to the specimen edge above and below the fracture plane. The second heating zone, consisting of two areas on either side of the first zone, was heated by two outward pairs of heaters. Temperature levels in the two zones were independently controlled to better achieve and maintain a linear thermal gradient.

The cold edge of the specimen (notch) was cooled by spraying liquid nitrogen $\left(i N_{2}\right.$ ) directly onto the specimen surface using a copper-tube manifold system. The specimen cooling level could be controlled by manually setting a hand value and with an on/off temperature controller interfaced with a thermocouple at the cold edge of the specimen. 
- THERMOCOUPLE LOCATKN

BOXED NUMBER INOICATES THERMOCOUPLE ON BACK OF SPECIMEN

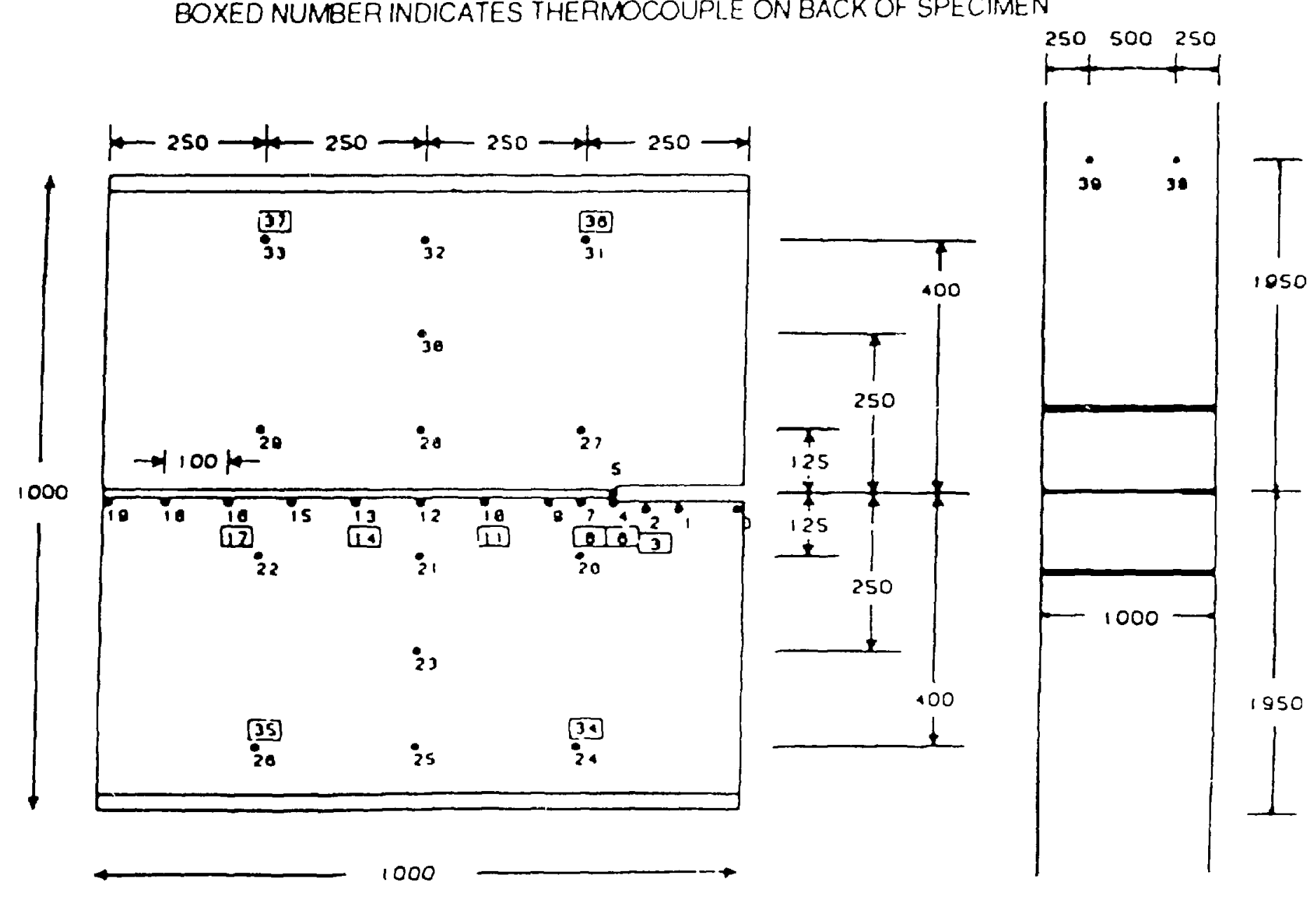

ALL OIMENSIONS IN MILLIMETERS

F1g. 2. Thermocouple locations for a typlcal HSST wide-plate crack-arrest specimen. 

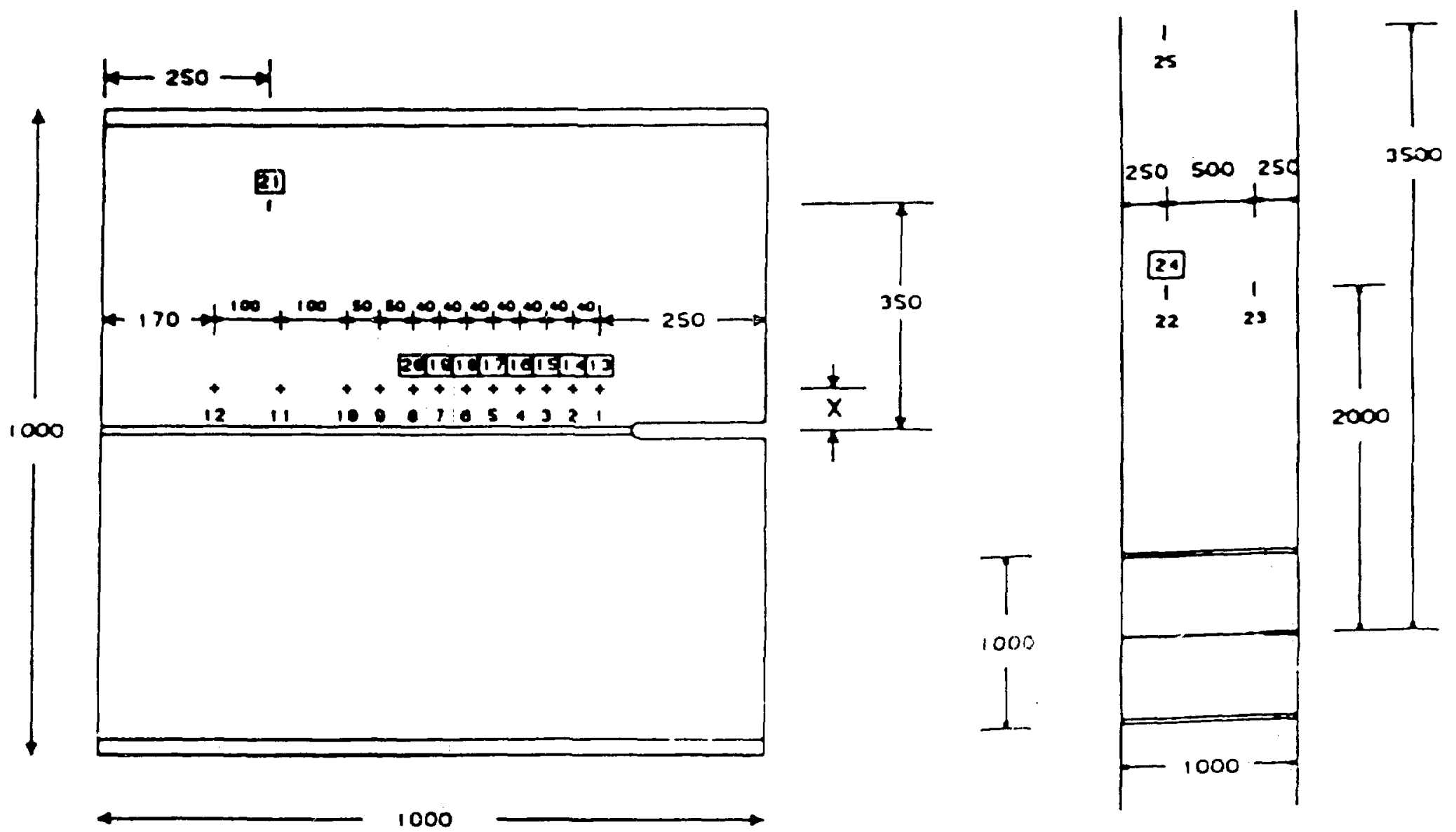

$x=97.5$ FOR WP.1.7 $x=65$ FOR WP.CE 1

ALL DIMENSIONS IN MILLIME TERS

F1g. 3. Strain gage locations for a typical HSST we-plate crackarrest specimen. 


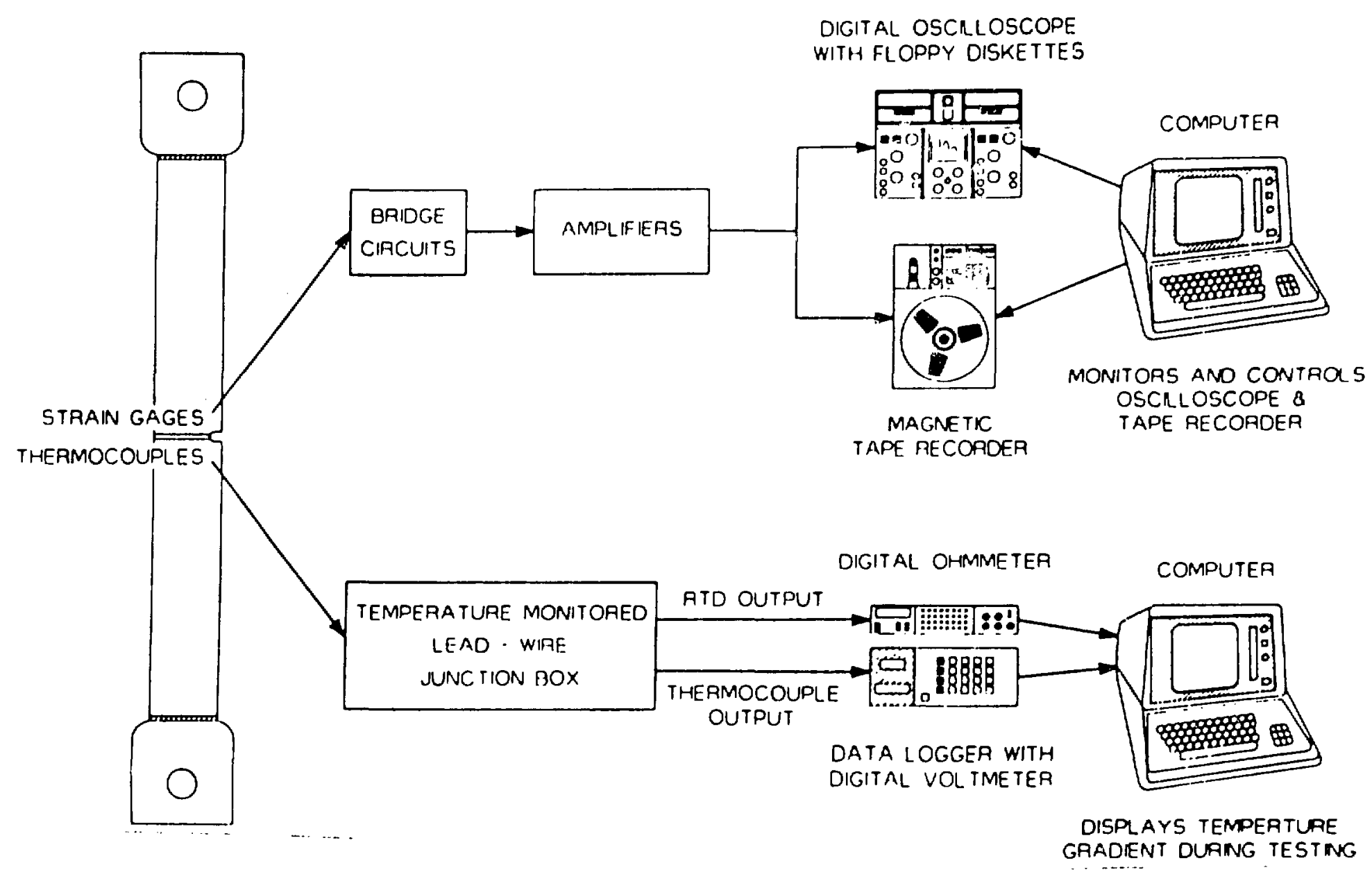

F1g. 4. Schematic of HSST wide-plate crack-arrest data acquisition system. 
Two types of thermal Insulation were used to Insulate the hot and cold edges of the specimen. On the hot edge of the plate mineral wool bats were positioned on the specimer: face at the vertlcal center line and extended beyond the heated edge and the strip heaters. The cold side of the plate was insulated with styrofoam sheets which butt up against the mineral wool at the specimen center and extend beyond the cooled edge.

\subsection{Testing Procedure}

After completion of specimen insulation, all instrumentation was atcached to the data acquisition system and a checkout conducted to demonstrate operabil1ty. A temperature gradient was lmposed across the plate by $\mathrm{LN}_{2}$ cooling of the notched edge while heating the other edge. Liquid nitrogen flow and power to the heaters were continuously adjusted to obtain the desired thermal gradient. Generally, the mid-plate $(a / w=0.5)$ temperature was solected to correspond to that of the onset of Charpy upper-shelf energy for the material being tested and the crack-tip temperature was varied to provide the desired Initiation load. Final calibration of the strain gages, COD gages and the load cell were completed just prior to initiation of specimen loading. Tensile load was then applied (Fig. 5) to the specimen at a rate of 11 to $312 \mathrm{kN} / \mathrm{s}$ until fracture occurred. Four exceptlons to this procedure occurred during the fifteen tests conducted to date. Specimens WP-1.1, WP-CE-2 and WP-2. 2 were initially warm prestressed to guard against initiation at a low load, and specimen WP-1.4 utilized a pillow jack device to initiate crack propagation at a prescribed tensile load.

\section{TEST SUMMARY}

\subsection{WP-1 Test Series}

Table 4 presents a summary of conditions for each test in the WP-1 test series. The fracture surfaces for specimens WP-1.1 through WP-1.6 are presented in Fig. 6, and FIg. 7 presents the fracture surfaces for specimens WP-1.7 and WP-1.8. Since a description of tests WP-1.1 through WP-1.7 has been presented in a previous paper [4], it will not be repeated. Only a summary of test WP-1.8 will be provided.

Test WP-1.8 was the seventh test in the WP-1 serles and the second which utilized a 152-mm-thick specimen. After obtaining a satisfactory thermal gradlent, the specimen was loaded at an average rate of $20 \mathrm{kN} / \mathrm{s}$ until $24.5 \mathrm{MN}$ was reached. Since a crack run-arrest event did not occur, the opecimen was rapidly unloaded $1 \mathrm{n}$ an effort to sharpen the crack tip prior to application of a second load cycle. Two changes were then made in the testing procedure prior to application of a second load cycle: the crack tip temperature was lowered about $11^{\circ} \mathrm{C}$ to $-47^{\circ} \mathrm{C}$, and the specimen loading rate was increased to $312 \mathrm{kN} / \mathrm{s}$. At a load of $26.5 \mathrm{MN}$, the crack run-arrest events inltlated and lasted $\sim 34 \mathrm{~ms}$ (cleavage crack propagation plus ductile tearing). Examlnation of the fracture surface ai:d strain gage records indicated that three cleavage crack run-arrest events had occurred. 


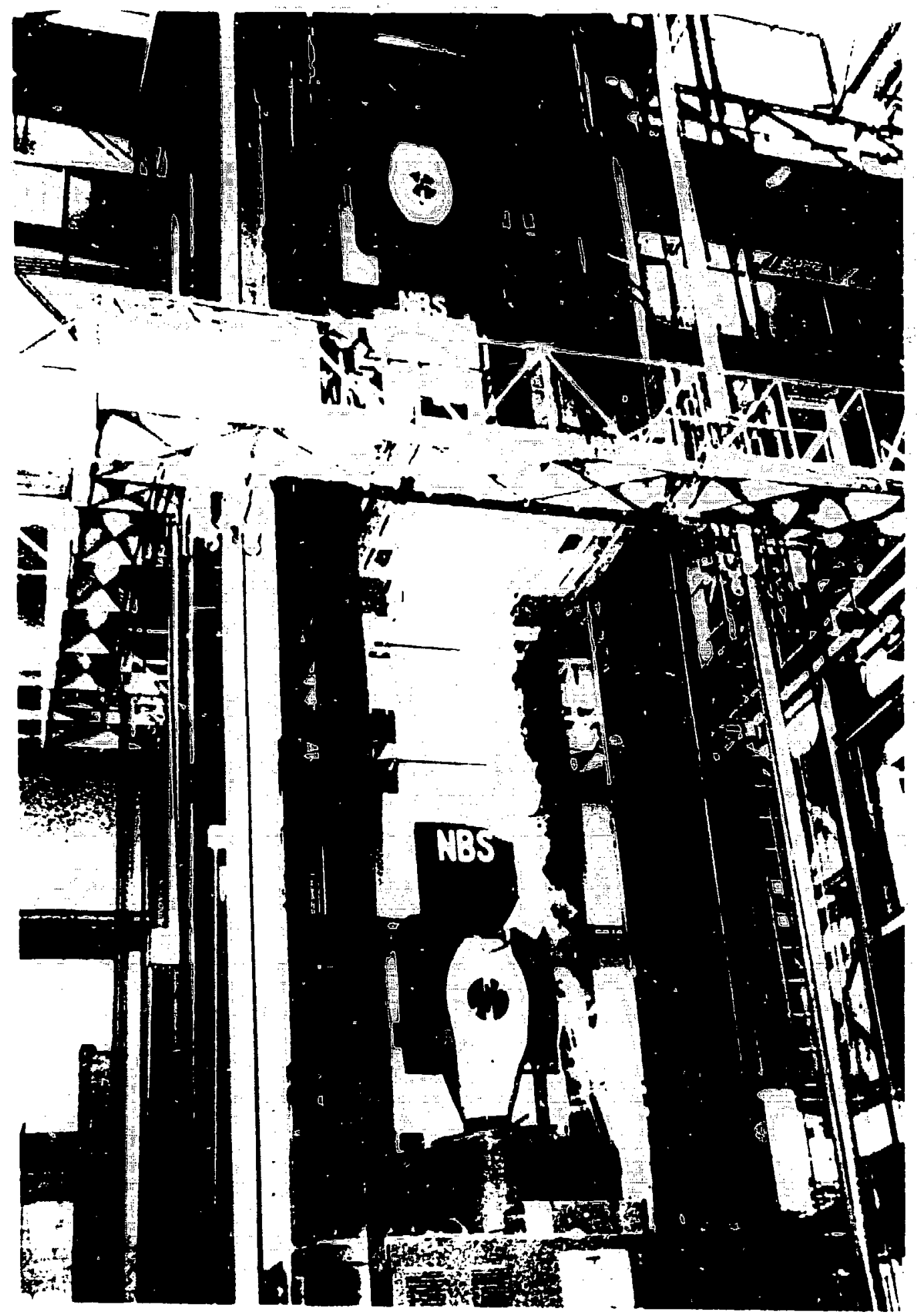

Fig. 5. wide hate ratingarres: specimen under test. 


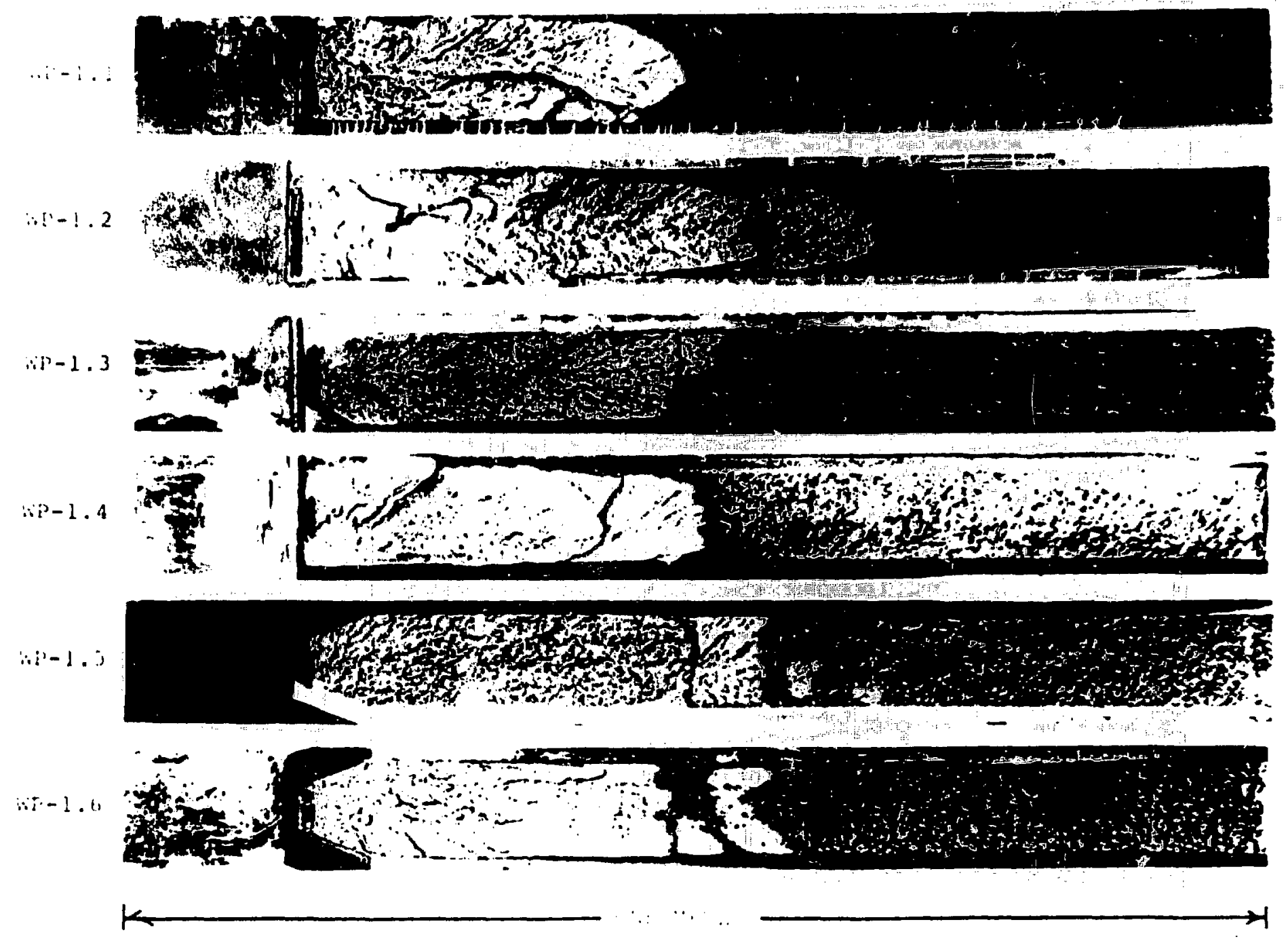

F1g. 6. Fracture surfaces of specimens WP-1.1 through WP-1.6. 


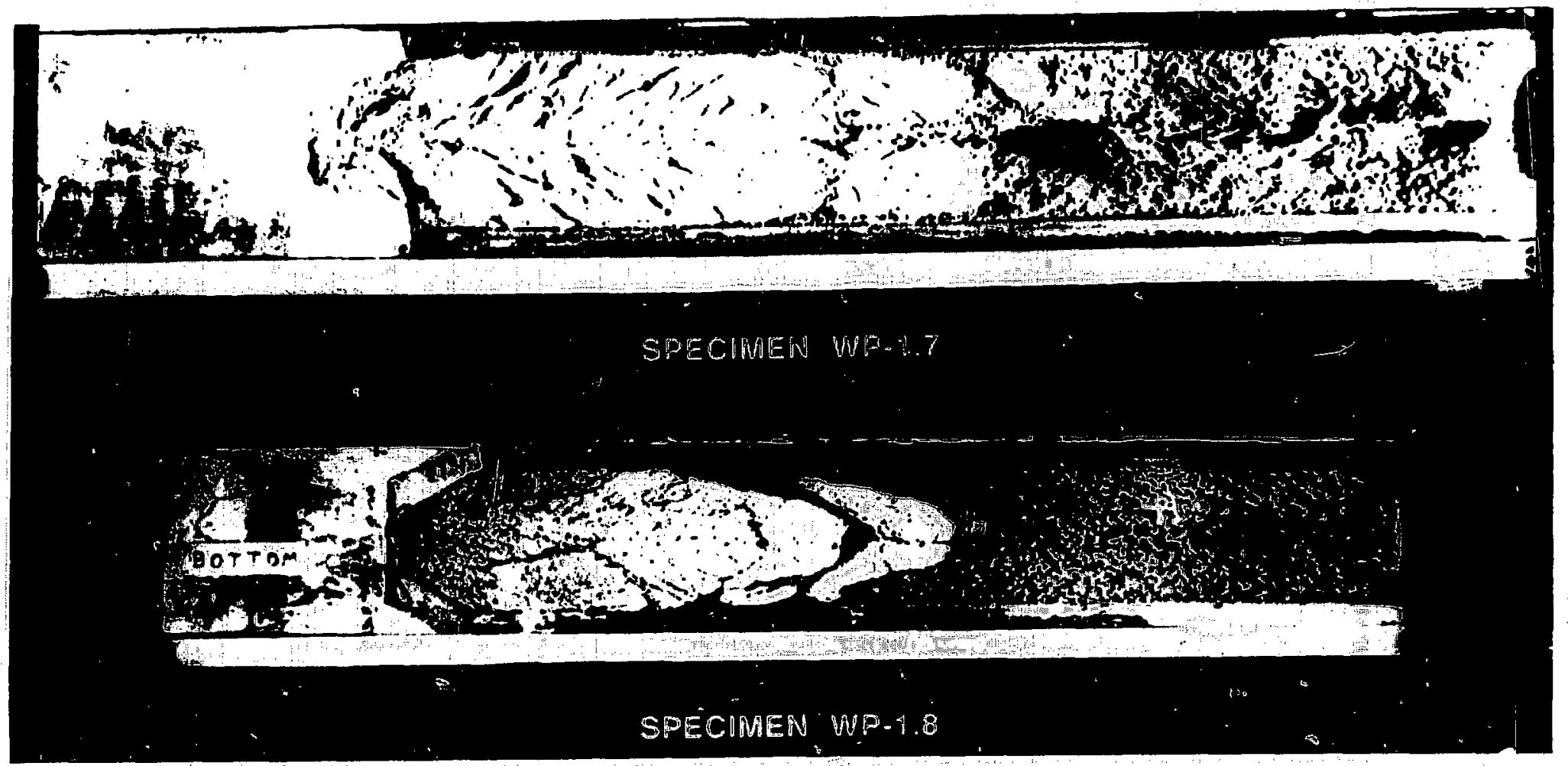

Fig. 7. Fracture surfaces of $152-m i n-t h i c k$ specimens WP-1.7 and $W P-1.8$. 
TABLE: 4

SUMMAKY UF IISST WIUE-PLATE CRACK-ARREST TEST CONUITIONS

FOR AS33 CRADE \& CLASS I STEEL: WP-1 AND WP-CE SERIES

\begin{tabular}{|c|c|c|c|c|c|c|}
\hline $\begin{array}{l}\text { Test } \\
\text { No. }\end{array}$ & $\begin{array}{l}\text { Crack } \\
\text { location } \\
\text { (c⿴囗十) }\end{array}$ & $\begin{array}{c}\text { Crack } \\
\text { temperature } \\
\left({ }^{\circ} \mathrm{C}\right)\end{array}$ & $\begin{array}{c}\text { Indtiation } \\
\text { load } \\
\text { (MN) }\end{array}$ & $\begin{array}{l}\text { Atrest } \\
\text { location } \\
\text { (cm) }\end{array}$ & $\begin{array}{c}\text { Arrest } \\
\text { temperature } \\
\left({ }^{\circ} \mathrm{C}\right)\end{array}$ & $\begin{array}{l}\text { Arrest } \\
\mathrm{T}-\mathrm{RT}_{\mathrm{NDT}} \\
\left({ }^{\circ} \mathrm{C}\right)\end{array}$ \\
\hline$H P-1.1^{a}$ & 20 & -60 & 20.1 & 50.2 & 51 & 74 \\
\hline$H P-1.2 A$ & 20 & -33 & 18.9 & 55.5 & 62 & 85 \\
\hline$W P-1.2 B$ & 55.5 & 62 & 18.9 & 64.5 & 92 & 115 \\
\hline$H P-1.3$ & $20^{b}$ & -51 & 11.25 & 48.5 & 54 & 77 \\
\hline$W P-1.4 \mathrm{~A}$ & $20.7^{b}, c$ & -63 & 7.95 & $44 . i$ & 29 & 52 \\
\hline$W P-1.4 B$ & 44.1 & 29 & 9.72 & 52.7 & 60 & 83 \\
\hline WP-1.5A & $2 u^{b}$ & -30 & 11.03 & 52.1 & 56 & 79 \\
\hline$W P-1.53$ & 52.1 & 56 & 11.03 & 58.0 & 72 & 95 \\
\hline$W P-1.6 A$ & $20^{\circ}$ & -19 & 14.50 & 49.3 & 54 & 77 \\
\hline $\mathrm{AP}-1.6 \mathrm{~B}$ & 49.3 & 54 & 14.50 & 59.3 & 80 & 103 \\
\hline WP-1.7A & $20.2^{b}$ & -24 & 26.2 & 52.8 & 61 & 84 \\
\hline WP-1.7B & 52.8 & 61 & 26.2 & 63.5 & 88 & 111 \\
\hline$W P-1.3 A$ & $19.8^{b}$ & -47 & 26.5 & 44.9 & 40 & 63 \\
\hline $4 P-1.8 B$ & 44.9 & 40 & 26.5 & 50.4 & 55 & 78 \\
\hline$W P-1.8 C$ & 50.4 & 55 & 26.5 & 59.4 & 79 & 102 \\
\hline$W P-C E-I$ & $20.0^{b}$ & -34 & 10.14 & 42.0 & 36 & 70 \\
\hline$W P-C E-2 A^{d}$ & $20.0^{b}$ & -40 & 14.60 & 46.6 & 42 & 76 \\
\hline $\begin{array}{l}W P-C E-2 B \\
W P-C E-2 C\end{array}$ & $\begin{array}{l}46.6 \\
50.4\end{array}$ & $\begin{array}{l}42 \\
51\end{array}$ & $\begin{array}{l}14.60 \\
14.60\end{array}$ & $\begin{array}{l}50.4 \\
52.5\end{array}$ & $\begin{array}{l}53 \\
60\end{array}$ & $\begin{array}{l}88 \\
95\end{array}$ \\
\hline
\end{tabular}

a Specimen was warm prestressed by loading to $10 \mathrm{MN}$ at $70^{\circ} \mathrm{C}$. Speclmen was also preloaded to $19 \mathrm{MN}$.

${ }^{b}$ Crack front cut to truncated chevron configuration.

CPillow jack utilized to apply pressure load to specimen's machined notch.

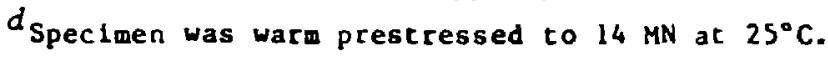

\subsection{WP-CE Test Series}

Table 4 presents a summary of the conditions for the two tests in the WP-CE test series. The fracture surfaces for the two specimens comprising this test serles are presented In F1g. 8 .

Test WP-CE-1 was the first wide-plate crack-arrest test which used the A 533 grade $B$ class 1 materlal provided by Combustion Engineering, Inc. After 


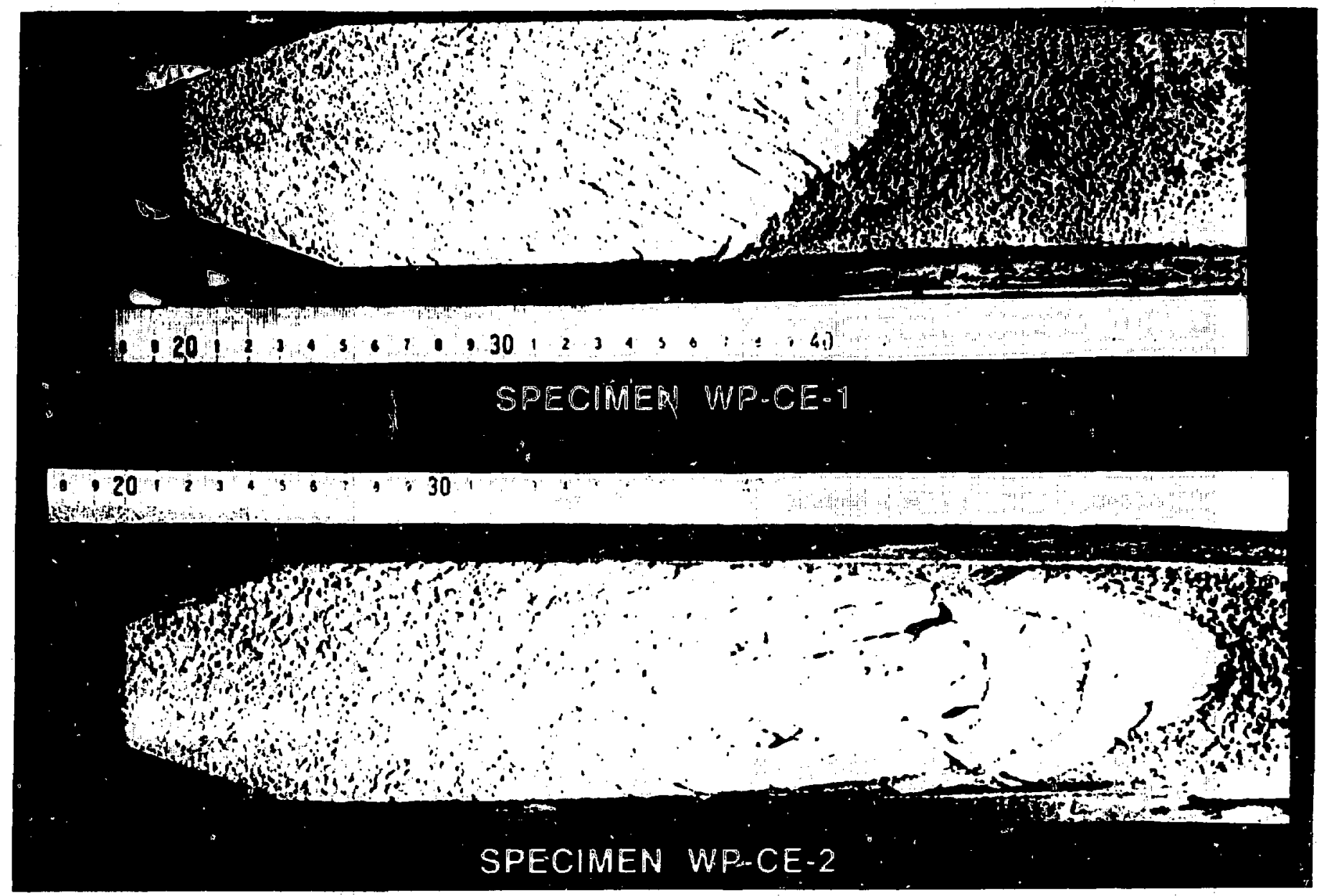

Fig. 8. Fracture surfaces of specimens WP-CE-1 and WP-CE-2. 
obcaining a satisfactory thermal gradient, the spectmen was loaded at an average rate of $24 \mathrm{kN} / \mathrm{s}$. At a load of $10.14 \mathrm{MN}$, cleavage crack propagation initiated with a stable arrest occurring at $a / w=0.37$ on the plate front face and $a t a / w=0.42$ on the plate back face. After holding the load constant for $150 \mathrm{~s}$, loading was reinltlated at $24 \mathrm{kN} / \mathrm{s}$. At a load of $15.26 \mathrm{MN}$, flbrous crack propagation began and was followed by a rapid drop in load to about 4.4 MN. After malntalning the load at thls value for about $30 \mathrm{~s}$, loading was reinitiated at $24 \mathrm{kN} / \mathrm{s}$ until at a load of $6.34 \mathrm{MN}$, complete separation of the plate occurred.

Prior to testing, specimen WP-CE-2 was warm prestressed at room temperature $\left(\sim 25^{\circ} \mathrm{C}\right)$ by loading it to $14 \mathrm{MN}$, holding the load for 5 minutes, and slowly reducing the load to $5 \mathrm{MN}$. While maintalning the load at $5 \mathrm{MN}$, the temperature gradient was developed. Having established a satisfactory thermal gradient, the specimen was loaded at a rate of $9.6 \mathrm{kN} / \mathrm{s}$. At a load ot 14.6 $M N$, the crack run-arrest events initlated. Examlnation of the fracture surface and straln gage records indicated that three cleavage crack run-arrest events occurred.

\subsection{WP-2 Test Series}

Table 5 presents a summary of the conditions for the tests in the WP- 2 series that have been conducted to date. The fracture surfaces for the five specimens that have been tested are presented in Fig. 9. Since a description of tests WP-2.4, WP-2.1, WP- 2.5 and WP-2.3 have been presented in a previous paper $[4,5]$, it will not be repeated. Only a summary of test WP-2.2 will be provided.

Prior to testing, specimen WP-2.2 was warm prestressed at $120^{\circ} \mathrm{C}$ by 1 oading it to $16 \mathrm{MN}$, holding the load for 5 minutes, and slowly reducing the load to $3 \mathrm{MN}$. While maintaining the load at $3 \mathrm{MN}$, the temperature gradient was developed. The specimen was loaded at a rate of $16.2 \mathrm{kN} / \mathrm{s}$. At a load of 17 $M N$, the crack run-arrest events initiated. Examination of the fracture surface and strain gage records Indicated that six to seven cleavage crack run-arrest events occurred.

\section{POSTTEST ANALYSES AND COMPARISON OF DATA WITH OTHER LARGE-SCALE TEST RESULTS}

\subsection{Posttest Analyses}

Posttest analyses were conducted for each wide-plate crack-arrest tast to investigate the interaction of parameters (plate geometry, material properties, temperature profile and mechanical loading) that affect the crack run arrest events. Three-dimensional (3-D), stat1c, finite-element analyses were performed to determine the stress-intensity factor at the time of crack initiation using the ORMGEN/ORVIRT [6,7] fracture analysis system in conjunction with the ADINA-84 [8] finite-element code. Quasistatlc analyses utilized the ORNL computer code WPSTAT [9] to evaluate the static stress-intensity factors as a function of crack length and temperature differential across the plate. WPSTAT also categorizes arrested crack lengths in terms of three types of 
lAst.l. 's

SUMHARY UF HSST WIDE-PLATE CRACK-ARREST TESL CONISTLONS FOR

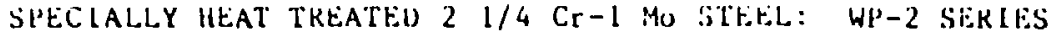

\begin{tabular}{|c|c|c|c|c|c|c|}
\hline $\begin{array}{l}\text { Test } \\
\text { No. }\end{array}$ & $\begin{array}{l}\text { Crack } \\
\text { location } \\
(c, 0)\end{array}$ & $\begin{array}{c}\text { Crack } \\
\text { cemperature } \\
\left({ }^{\circ} \mathrm{C}\right)\end{array}$ & $\begin{array}{l}\text { Inlciation } \\
\text { load } \\
\text { (MN) }\end{array}$ & $\begin{array}{l}\text { Arrest } \\
\text { location } \\
(\mathrm{cm})\end{array}$ & $\begin{array}{l}\text { Arrest } \\
\text { cemperacure } \\
\left({ }^{\circ} \mathrm{C}\right)\end{array}$ & $\begin{array}{l}\text { Arrest } \\
\mathrm{T}-\mathrm{RT}_{\mathrm{NDT}} \\
\left({ }^{\circ} \mathrm{C}\right)\end{array}$ \\
\hline$W P-2.4 A^{a}$ & $20.3 \mathrm{~h}$ & 45 & 7.52 & 25.1 & 61 & 1 \\
\hline$W P-2.4 B$ & $25.1^{b}$ & 61 & 8.85 & 33.8 & 86 & 26 \\
\hline$W P-2.4 C$ & 33.8 & 86 & 8.85 & 39.7 & 102 & 42 \\
\hline$W P-2.4 D$ & 39.7 & 102 & 8.85 & 41.3 & 107 & 47 \\
\hline$W P-2.4 E$ & 41.3 & 107 & 8.85 & 46.2 & 121 & 61 \\
\hline$W P-2.4 F$ & 46.2 & 121 & 8.85 & 48.4 & 127 & 67 \\
\hline$W P-2.4 G$ & 48.4 & 127 & 8.85 & 51.5 & 137 & 77 \\
\hline $\mathrm{HP}-2.41 \mathrm{t}$ & 51.5 & 137 & 8.85 & 55.5 & 149 & 89 \\
\hline$W E-2.1 A^{a}$ & 19.9 & 55 & 11.90 & 27.5 & 80 & 20 \\
\hline$W P-2.1 B$ & 27.5 & 80 & 11.90 & 33.5 & 96 & 36 \\
\hline$W P-2.1 \mathrm{~V}$ & 33.5 & 96 & 11.90 & 37.0 & 105 & 45 \\
\hline$W P-2.1 E$ & 37.0 & 105 & 11.90 & 40.0 & 112 & 52 \\
\hline$W P-2.1 F$ & 40.0 & 112 & 11.90 & 45.0 & 125 & 65 \\
\hline$W P-2.1 H$ & 45.0 & 125 & 11.90 & 49.0 & 135 & 75 \\
\hline$W P-2.1 I$ & 49.0 & 135 & 11.90 & 52.7 & 145 & 85 \\
\hline$W P-2.1 \mathrm{~J}$ & 52.7 & 145 & 11.90 & 55.5 & 152 & 92 \\
\hline$\therefore P-2.5 A^{a}$ & 14.9 & 66 & 7.53 & 27.2 & 86 & 26 \\
\hline HP $-2.5 B$ & $2 i \cdot 2^{b}$ & 86 & 8.90 & 35.0 & 104 & 44 \\
\hline$W P-2.5 C$ & 35.0 & 104 & 8.90 & 43.5 & 124 & 64 \\
\hline$W P-2.5 D$ & 43.5 & 124 & 8.90 & 47.8 & 135 & 75 \\
\hline$W P-2.5 E$ & 47.8 & 135 & 8.90 & 51.6 & 144 & 84 \\
\hline$W P-2.5 F$ & 51.6 & 144 & 8.90 & 56.0 & 154 & 94 \\
\hline $\mathrm{WP}-2.3 \mathrm{~A}$ & 20.0 & 66 & 15.3 & 34.0 & 97 & 37 \\
\hline WP-2. 3B & 34.0 & 97 & 15.3 & 37.5 & 106 & 46 \\
\hline$W P-2.30$ & 37.5 & 106 & 15.3 & 39.7 & 111 & 51 \\
\hline WP-2.3F & 39.7 & 111 & 15.3 & 45.7 & 126 & 66 \\
\hline $\mathrm{NP}-2.2 \mathrm{~A}^{\alpha}$ & 21.1 & 58 & 17.0 & 43.5 & 120 & 60 \\
\hline $\mathrm{HP}-2.2 \mathrm{~B}$ & 43.5 & 120 & 17.0 & 46.5 & 129 & 69 \\
\hline$W P-2.2 C$ & 46.5 & 129 & 17.0 & 47.8 & 133 & 73 \\
\hline$W P-2.2 D$ & 47.8 & 133 & 17.0 & 49.9 & 139 & 79 \\
\hline $\mathrm{WP}-2.2 \mathrm{E}$ & 49.9 & 139 & 17.0 & 51.0 & 142 & 82 \\
\hline$W P-2.2 F$ & 51.0 & 142 & 17.0 & 53.8 & 150 & 90 \\
\hline$W P-2.2 G$ & 53.8 & 150 & 17.0 & 58.2 & 162 & 102 \\
\hline
\end{tabular}

$a_{\text {Crack }}$ front cuc to chevron configuracion.

$b_{\text {Af cer pop-in. }}$ 


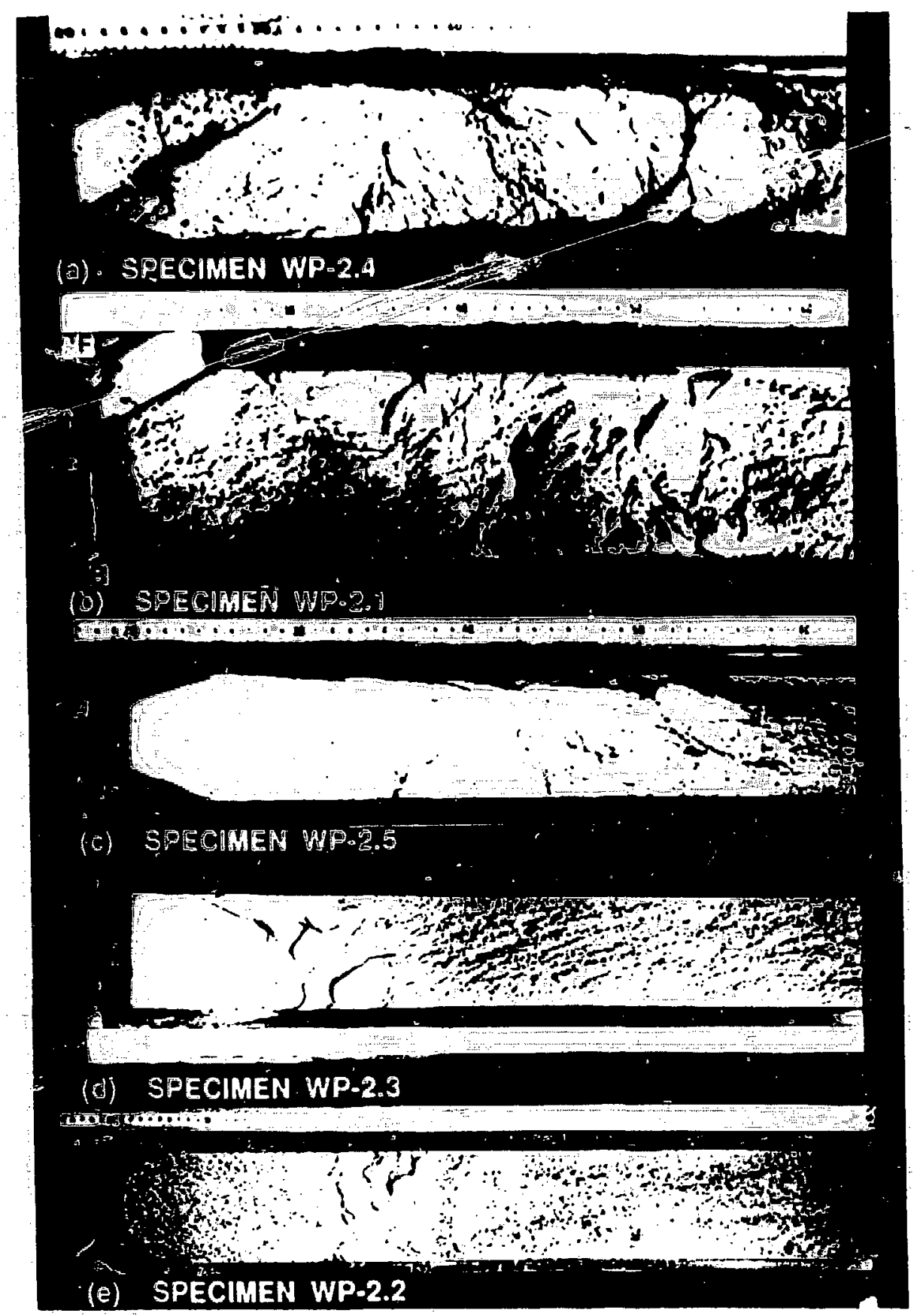

Fig. 9. Fractire surfices of specineris wp-2.4, -2.1, -2.5, -2. atid-2. 2 . 
instablitity limits; l.e., reintelation, tearling instabllity and tensile instability. Elastodynamlc analyses are carrled out using the ADINA/VPF (8) dynaluic crack analysis code. The code is capable of performing both application-mode (crack tip ls propagated lncrementally when $K_{I}$, the dynamically computed stress-intensity factor, equals the specifled dynamic fracture toughness value, $K_{I D}$ ) and generation-mode (crack tip is propagated incrementally according to a prescribed crack posicion vs time relationship with the values of fracture toughness decermined from the dynamlcally computed $K_{I}$ ) analyses. For both modes of analysis, the dynamlc stress-intensity factor is determined in each time step from the dynamic J-integral containing the appropriate inertial and thermal terms.

Tables 6 and 7 summarize crack-arrest toughness values for th: WP-1, WP-CE and WP-2 series, which were computed by both static and dynamic analyses as well as those determined using handbook techniques $[11,12]$. The dynamic generation-wode (flxed-load) crack-arrest toughness results, presented in Fig. 10, extend consistently above the limit provided in ASME Sect. XI and exhibit a signiflcant increase in toughness with temperature ( $T-R_{N D F}$ ). This Increase in arrest toughness with temperature occurs at an accelerating rate suggesting that a temperature limit exists at or below which a cleavage crack propagation will arrest, no matter how high the applied driving force.

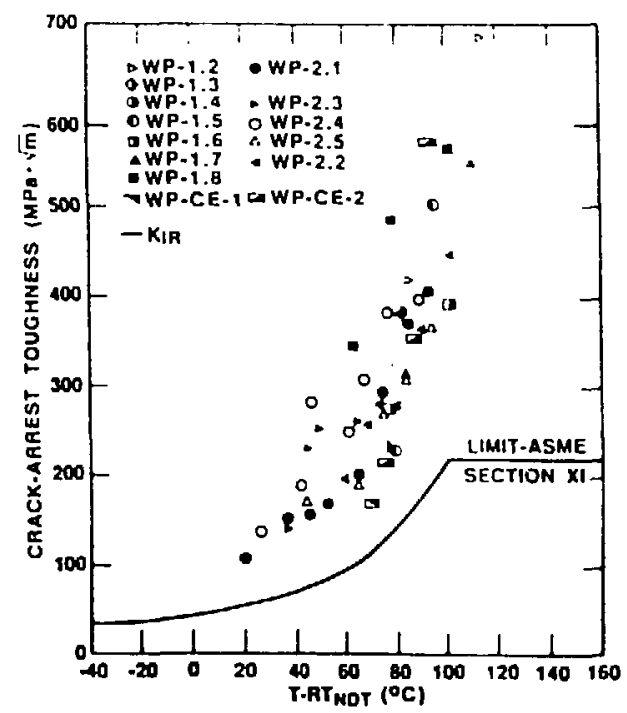

Fig. 10. Generation-mode (f Ixed load) crack-arrest toughness data versus temperature $\left(\mathrm{T}-\mathrm{RT}_{\mathrm{NDT}}\right.$ ) for HSST wide-plate tests.

\subsection{Comparison of Data with Other Large-Scale Test Results}

The trend for $K_{I a}$ values to extend consistently above the limit provided in ASME Sect. XI is further substantiated in Fig. 11, which presents data from several large-scale tests [13-24] plus the wide-plate test results. 
[ABLE t

SURIAKY UF CKACK-ARREST TUUCHNLSS VALUTSS

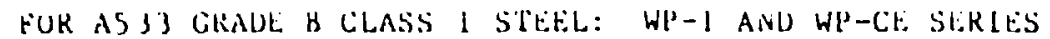

\begin{tabular}{|c|c|c|c|c|}
\hline \multirow{3}{*}{$\begin{array}{l}\text { Test } \\
\text { No. }\end{array}$} & \multicolumn{4}{|c|}{$\begin{array}{c}\text { Crack-arrest toughness values } \\
\text { (MPa. } \sqrt{\mathrm{m}})\end{array}$} \\
\hline & \multicolumn{2}{|c|}{ static SEN formulas } & \multirow{2}{*}{$\begin{array}{l}\text { Fedderson } \\
\text { alternace } \\
\text { secant } c \\
\text { formula }\end{array}$} & \multirow{2}{*}{$\frac{\text { Uynamlc } F E^{d}}{\begin{array}{c}\text { Ceneration } \\
\text { mode }\end{array}}$} \\
\hline & $\begin{array}{l}\text { DLspl. } a \\
\text { concrol }\end{array}$ & $\begin{array}{l}\text { Load } \\
\text { control }\end{array}$ & & \\
\hline$W P-1.1$ & 391 & 813 & 340 & NA \\
\hline $\begin{array}{l}W P-1.2 A \\
W P-1.2 B\end{array}$ & $\begin{array}{l}384 \\
416\end{array}$ & $\begin{array}{r}942 \\
1489\end{array}$ & $\begin{array}{l}349 \\
419\end{array}$ & $\begin{array}{l}424 \\
685\end{array}$ \\
\hline$W P-1.3$ & 215 & 424 & 185 & 235 \\
\hline$W P-1.4 A$ & 145 & 248 & 120 & $\mathrm{NA}$ \\
\hline$W P-1.4 B$ & 331 & 433 & 170 & 387 \\
\hline$W P-1.5 A$ & 217 & $\begin{array}{l}472 \\
616\end{array}$ & $\begin{array}{l}191 \\
213\end{array}$ & $\begin{array}{l}231 \\
509\end{array}$ \\
\hline$W P-1.5 B$ & & & & \\
\hline $\begin{array}{l}W P-1.6 \mathrm{~A} \\
W P-1.6 \mathrm{~B}\end{array}$ & $\begin{array}{l}279 \\
306\end{array}$ & $\begin{array}{l}565 \\
881\end{array}$ & $\begin{array}{l}242 \\
290\end{array}$ & $\begin{array}{l}275 \\
397\end{array}$ \\
\hline WP-1.7A & 351 & 793 & 311 & 319 \\
\hline$W P-1.7 \mathrm{~B}$ & 385 & 1312 & 381 & 555 \\
\hline$W P-1.8 A$ & 325 & 576 & 273 & 345 \\
\hline$W P-1.8 B$ & 344 & 723 & 301 & 484 \\
\hline HP-L . 8C & 374 & 1083 & 350 & 563 \\
\hline$W P-C E-1$ & 180 & 293 & 148 & 170 \\
\hline $\mathrm{HP}-\mathrm{CE}-2 \mathrm{~A}$ & 274 & 509 & 232 & 218 \\
\hline$W P-C E-2 B$ & 285 & 597 & 249 & 354 \\
\hline$W P-C E-2 C$ & 291 & 653 & 258 & 576 \\
\hline \multicolumn{5}{|c|}{ 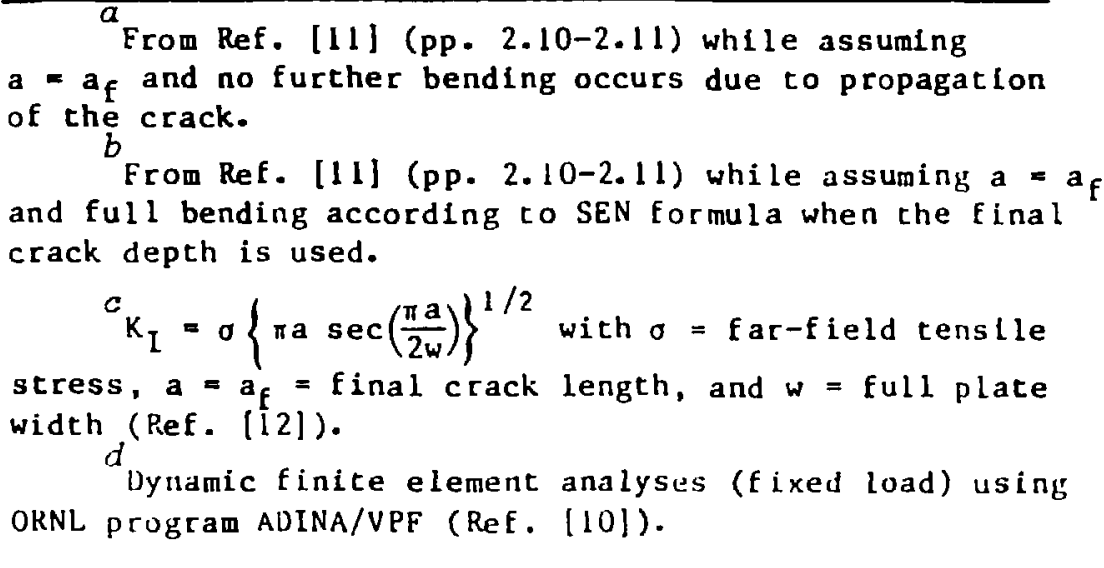 } \\
\hline
\end{tabular}


IABLE 1

SUMMAKY UF CKACK-ARKEST TUUCHNESS VALUES FUK TILE WH-2 TEST SEKIES

\begin{tabular}{|c|c|c|c|c|}
\hline \multirow{3}{*}{$\begin{array}{l}\text { Tesi } \\
\text { No. }\end{array}$} & \multicolumn{4}{|c|}{$\begin{array}{c}\text { Crack-arrese coughness values } \\
\text { (MPa-d })\end{array}$} \\
\hline & \multicolumn{2}{|c|}{$\begin{array}{l}\text { Tada } \\
\text { gtat Ic SEN formulag }\end{array}$} & \multirow{2}{*}{$\begin{array}{l}\text { Feddecson } \\
\text { alternate } \\
\text { cecant } \\
\text { formulac }\end{array}$} & \multirow{2}{*}{$\frac{\text { Dynamlc FEd }}{\substack{\text { Ceneration } \\
\text { mode }}}$} \\
\hline & $\begin{array}{l}\text { Displ. } \\
\text { controla }\end{array}$ & $\begin{array}{l}\text { Load } \\
\text { control } b\end{array}$ & & \\
\hline$W P-2.4 A$ & 104 & 113 & 79 & --- \\
\hline$W P-2.4 B$ & ISS & 186 & 111 & 137 \\
\hline $\begin{array}{l}W P-2.4 C \\
W P-2.40\end{array}$ & $\begin{array}{l}168 \\
171\end{array}$ & $\begin{array}{l}234 \\
249\end{array}$ & $\begin{array}{l}124 \\
128\end{array}$ & $\begin{array}{l}188 \\
28 !\end{array}$ \\
\hline $\begin{array}{l}W P-2.40 \\
W P-2.4 F\end{array}$ & $\begin{array}{l}171 \\
181\end{array}$ & $\begin{array}{l}249 \\
303\end{array}$ & $\begin{array}{l}128 \\
140\end{array}$ & $\begin{array}{l}281 \\
249\end{array}$ \\
\hline $\begin{array}{l}W P-2.4 F \\
W P-2.49\end{array}$ & $\begin{array}{l}181 \\
185\end{array}$ & 332 & $\begin{array}{l}140 \\
145\end{array}$ & $\begin{array}{l}249 \\
307\end{array}$ \\
\hline $\begin{array}{l}W P-2.49 \\
W P-2.65\end{array}$ & 191 & 378 & 153 & 381 \\
\hline $\begin{array}{l}W P-2.65 \\
W P-2.4 H\end{array}$ & 198 & 451 & 165 & $\begin{array}{l}381 \\
397\end{array}$ \\
\hline WH-2.4H & $-\infty$ & 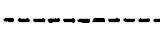 & & 391 \\
\hline $\mathrm{WP}-2.1 \mathrm{~A}$ & 114 & 132 & 88 & 106 \\
\hline $\begin{array}{l}W P-2.1 \mathrm{~A} \\
W P-2.1 \mathrm{~B}\end{array}$ & 126 & 166 & 100 & 106 \\
\hline$W P-2.1 B$ & & & & 153 \\
\hline$H P-2.10$ & 133 & 190 & 106 & 158 \\
\hline$W P-2.1 E$ & 138 & 213 & 112 & 170 \\
\hline$W P-2.1 \mathrm{f}$ & 146 & 260 & 123 & 201 \\
\hline$W P-2.1 \mathrm{H}$ & 153 & 306 & 132 & 293 \\
\hline$W P-2.1 I$ & 158 & 359 & 141 & 371 \\
\hline$W P-2.1 \mathrm{~J}$ & 163 & 406 & 149 & 406 \\
\hline$H P-2.5 A$ & 108 & 123 & 83 & -- \\
\hline$W P-2.5 B$ & 165 & 196 & 114 & 171 \\
\hline$W P-2.5 C$ & 184 & 273 & 134 & 190 \\
\hline$H P-2.5 D$ & 193 & 326 & 144 & 268 \\
\hline WP-2.SE & 200 & 382 & 155 & 306 \\
\hline WP-2.5F & 209 & 464 & 167 & 366 \\
\hline$W P-2.3 A$ & 164 & 217 & 129 & 144 \\
\hline$H P-2.3 B$ & 172 & 249 & 138 & 232 \\
\hline WP-2.3D & 177 & 271 & 144 & 255 \\
\hline WP- $2.3 F$ & 190 & 344 & 160 & 258 \\
\hline $\begin{array}{l}W P-2.2 A \\
W P-2.2 B\end{array}$ & $\begin{array}{l}210 \\
217\end{array}$ & $\begin{array}{l}350 \\
395\end{array}$ & $\begin{array}{l}171 \\
180\end{array}$ & $\begin{array}{l}201 \\
259\end{array}$ \\
\hline $\mathrm{HP}-2.2 \mathrm{C}$ & 220 & 416 & 185 & 281 \\
\hline$W P-2.2 D$ & 225 & 454 & 192 & 299 \\
\hline$W P-2.2 E$ & 227 & 476 & 195 & 380 \\
\hline$W P-2.2 F$ & 233 & 538 & 206 & 364 \\
\hline$W P-2.2 C$ & 242 & 656 & 223 & 446 \\
\hline
\end{tabular}

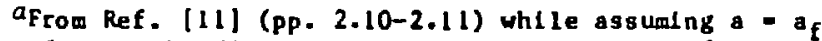
and no further bending occurs due to propagation of the crack.

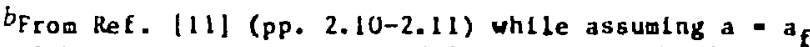
and $f u l l$ bending according to SEN formula when the final crack depth ls used.

$$
c_{K_{I}}-\sigma\left\{x a \sec \left(\frac{w a}{2 u}\right)\right\}^{1 / 2} \text { with a }-f a r-f i e l d \text { tensile }
$$

stress, a - af = f inal crack length, and $w$ - full plate width (Ref. $\mid\{2 \mid)$.

$$
d_{\text {Dynamlc }} \text { intte element analyses (f lxed load) using }
$$
ORNL program ADINA/VPF (Ref. $(10)$ ). 


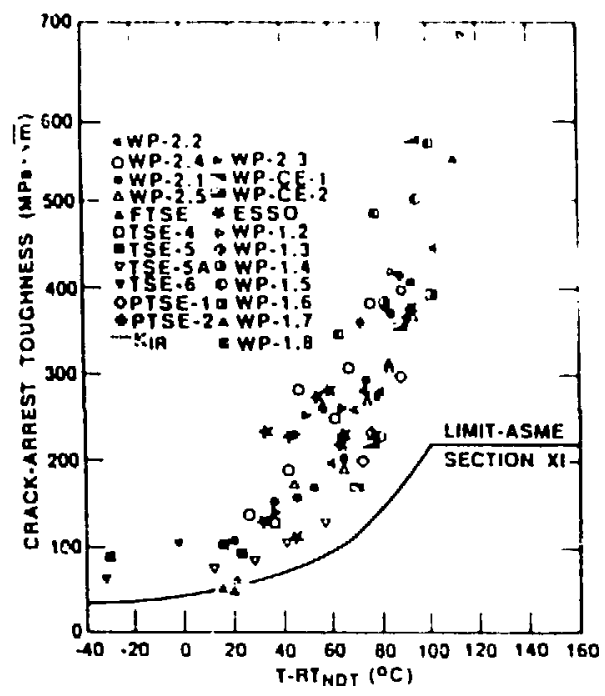

Fig. 1 1. High temperature crack-arrest toughness data versus temperature ( $T-R_{N D T}$ ) for wide-plate and other large specimen tests.

\section{CONCLUSIONS}

In conclusion, the HSST program has an integrated effort underway to extend the range of applicability of current state-of-the-art crack-arrest practices and to devalop alternatives where improvements are needed. Fractographic examinations confirm that the crack propagation in the wide-plate tests occurred by a predominately cleavage mode and that the arrest events were not preceded by conversion to ductile tearing. Arrest may be followed by stable or unstable ductile crack growth, but these modes of fracture may be analyzed independent of the cleavage run-arrest events. A consistent trend is formed when the crack-arrest data from the three types of HSST large-specimen tests are combined on a plot of $\mathrm{K}_{\mathrm{Ia}}$ vs $\mathrm{T}-\mathrm{RT}_{\mathrm{NDT}}$ with other large-specimen data. Collectively these data show that arrest can and does occur at temperatures up to and above that which corresponds to the onset of Charpy upper-shelf behavior, and the measured $K_{I a}$ values extend above the limit included in Section XI of the AEME code. Further, the data suggest the existence of a limiting temperature above which a cleavage crack cannot propagate no matter how high the applied driving force. In summary, the data being obtalned under the HSST wide-plate crack-arrest program support: (1) the use of fracturemechanics concepts to analyze cleavage run-arrest events, (2) the treatment of cleavage- and ductile-fracture modes as separate events, and (3) the fact that cleavage arrest can occur at toughness levels well above the ASME 1 imit. 
1. H. F. Kauninen et al. Preliminary Analysis of Japanese Wide-Plate Dynamic Crack Propagation Arrest Experiments, Subcontract report from Battelle Columbus Laboratorles to Oak Ridge Natlonal Laboratory, December 1983.

2. 0. J. Ayres et al., Appendix $G$, Material Characterization in Tests and Analyses of Crack Arrest in Reactor Vessel Mrterials, EPRI NP-5121-SP, prepared by Combusion Engineering, Inc., Hindsor, Conn., for Electric Power Research Institute, Palo Alto, Calif., April 1987.

3. G. A. Danko et al., Wide-Plate Crack-Arrest Tests: Instrumentation for Dynamic Strain Measurements, NBSIR 85-3289, Nacional Bureau of Standards, Gaithersburg, Maryland, December 1985.

4. D. J. Naus et al., "Summary of HSST Wide-Plate Crack Arrest Tests and Analyses," Proc. of the U.S. Nuclear Regulatory Commission Fifteenth Water Reactor Safety Information Meeting held at National Bureau of Standards, Gaithersburg, Maryland, NUREG/CP-0091, pp. 17-40, February 1988.

5. C. E. Pugh and D. J. Naus, "Integration of Wide-Plate Crack-Arrest Test Resulcs," Proc. of U.S. Nuclear Regulatory Conmisiion Fourteenth water Reactor Safety Information Meeting held at National Bureau of Standards, Gaithersburg, Maryland, NUREG/CP-0082, pp. 195-225, February 1987.

6. B. R. Bass and J. W. Bryson, Applications of Energy Release Rate Technique to Part-Through Cracks in Plates and Cylinders, Volume 1, ORMGEN3D: A Finite Element Mesh Generator for 3-Dimensional Crack Geometries, NUREG/CR-2997, Vol. l (ORNL/TM-8527/VI), Union Carbide Corp. Nuclear Div., Oak Ridge Natl. Lab., December 1982.

7. B. R. Bass and J. W. Bryson, Applications of Energy Release Rate Technique to Part-Through Cracks in Plates and Cylinders, Voiume 2, ORVIRT: A Finite Element Program for Energy Release Rate Calculations for $2-D$ and 3-D Crack Models, NUREG/CR-2997, Vol. 2 (OKNL/TM-8527/V2), Union Carbide Corp., Nuclear Div., Oak Ridge Natl. Lab., February 1983.

8. K. J. Bathe, ADINA - A Finite Element Program for Automatic Dynamic Incremental Nonlinear Analyses, Report A-l, Massachusetts Institute of Technology, Cambridge, Mass., 1984.

9. B. R. Bass, C. E. Pugh, and H. K. Stamm, "Dynamic Analyses of a Crack Run-Arrest Experiment in a Nonisothermal Plate," Pressure Vessel Components Design and Analysis, ASME Publication PVP, 98-2, 175-84, 1985.

10. B. R. Hass and J. Keeney-Walker, "Computer Program Development for Dynamic Fracture Aralysis," Pp. 5-12 in Heavy-Section Steel Technology Program Semiann. Prog. Rep. April-September 1985, NUREG/CR-4219, Vol. 2 (ORNL/Ti1-9593/V2), Martin Marietta Energy Systems, Inc., Oak Ridg! Natl. Lab. : January 1986. 
11. R. Tada, R. C. Paris, and L. R. Irwin, The Stress Analyois of Cracks Handbook, Del Research Corp., Hellertown, Pa., 1973.

12. C. F. Fedderson, Current Status of Plain Strain Crack Toughness Testing of High-Strength Metallic Materialo, Crack Arrest Methodology and Appl1cations, ASTM STP-410, Amerlcan Society for Testing and Materials, Philadelphia, Pa., 1967.

13. R. D. Cheverton et al., Pressure Vessel Eracture Studies Pertaining to the FWR Thermal-Shock Issue: Experiments TSE-5, TSE-SA, and TSE-6, NUREG/CR-4249 (ORNL-6163), Martin Marietca Energy Systems, Inc., Oak Ridge Natl. Lab., June 1985.

14. R. D. Cheverton et al., Pressure Vessel Eracture Studies Pertaining to the FWR Thermal-Shock Issue: Experiment TSE-7, NUREG/CR-4304 (ORNL6177). Martin Marietta Energy System, Inc., Oak Ridge Nat1. Lab., August 1985.

15. R. H. Bryan et al., Pressurized-Thermal-Shock Test of 6-in.-Thick Pressure Vessels. PTSE-1: Investigation of Warm Prestressing and UpperShelf Arrest, NUKEG/CK-4106 (ORNL-6135), Martin Mariecta Energy Systems, Inc., Oak Ridge Natl. Lab., April 1985.

16. R. H. Bryan et al., Preasurized-Thermal-Shock Teat of 6-in.-Thick Pressure Vessel6. PTSE-2: Investigation of Low Tearing Resistance and Warm Prestressing, NUREG/Ck-4888 (ORNL-6377), Martin Mariecta Energy Systems, Inc., Oak Ridge Nat1. Lab., December 1987.

17. Japan Welding Council, Stmuctural Integrity of Very Thick Steel Plate for Nuclear Reactor Pressure Vessels, JWES-AE-7806, 1977 (1n Japanese).

18. T. Kanazawa, S. Machida, and T. Teramoco, "Preliminary Approaches to Experimental and Numerical Study of Fast Crack Propagation ard Crack Arrest," PP. 39-58 in East Fracture and Crack Arrest, ASTM STP 627, American Society for Testing and Materlals, Philadelphia, Pa., 1977.

19. N. Ohashi et al., "Fracture Toughness of Heavy Section LWR Pressure Vessel Steel Plate Produced by Basic Oxygen Furnace and Ladle Refining Process," Proceedings of the Fourth International Conference on Pressure Vesael Technology, Vo1. 1, pp. 391-96, I. Mech. E., 1980.

20. T. Kanazawa et al., "Study on Fast Fracture and Crack Arrest," $E x-$ perimental Mechanics 21(2), 77-88 (February 1981).

21. S. Machida, Y. Kawaguchi, and M. Tsukamoto, "An Evaluation of the Crack Arrestability of $9 \%$ Ni Steel Plate to an Extremely Long Brittle Crack," Joumal of the Society of Naval Architeat of Japan 150, 511-17 (1981), translation ORNL-tr-5052. 
22. T. Kanazawa, S. Machida, and II. Yajima, "Recent Studles on Brittle Crack Propagation and Arrest in Japan," pp. $81-100$ in Fracture Mechanics Technology Applied to Material and Structure DeBign, C. C. Sih, N. E. kyan, and $K$. Jones (eds.), Marcinua Nijhoff, The llague, 1983.

23. Y. Nakano, "Stress Intensity Factor Durlng Britcle Crack Propagation and Arrest in ESSO Specimens," 18th National Symposium on X-Ray Study on Deformation and Fracture Solids, The Soc. of Materials Science, Japan, July 13-14, 1981 .

24. A. Pellissier-Tanon, P. Sollogoub, and B. Houssin, "Crack Initiation and Arrest in an SA 508 Class-3 Cylinder Under Liquid Nitrogen ThermalShock," Paper G/F 1/8, Transactions of the 7 th International Conference on Structural Mechanics in Reactor Technology, Vol. G/H, Pp. 137-42 (August 1983). 